of the liquid in the vessels employed. These phenomena he describes in a paper in the Chem. Centr., 1878, 35 I, and explains them by the supposition that the gas in its evolution throws up small portions of zinc, rendered porous by the action of the acid, and that these finelydivided particles coming in contact with the air act like spongy platinum, causing the gaseous mixture to explode. The spontaneous ignition of hydrogen has been observed by others, but no satisfactory explanation has been given of the action.

\section{METEOROLOGICAL NOTES}

CAPT. HOFFMEYER has made an original and highly important contribution to our knowledge of the distribution of atmospheric pressure in winter over the North Atlantic, and its influence on the climate of Europe, in the last published number of the Fournal of the Meteorological Society of Austria (October 15). The contribution takes the form of a rectification of Buchan's isobaric charts for this part of the globe, and, by a most ingenious and able method of investigation, entirely his own, Hoffmeyer conclusively shows that Greenland and Iceland exert a powerful influence on the distribution of atmospheric pressure not hitherto properly recognised, resulting in the mean minimum of pressure being localised distinctly to the south-west of Iceland-a minimum accompanied with two subordinate minima, one in Davis Straits and the other in the Arctic Ocean, mid-way between Jan Mayen and the Lofoden Isles. Four typical charts are also given, showing the actual mean pressure of as many individual winter months, from which it is plain that one or other of these three minima plays the chief roll, the other two being, for the time, subordinate; and that, according as the one or the other of these minima of pressure predominates, so is the character of the weather, as regards its mildness or severity, of the winter of the regions surrounding the North Atlantic, determined.

THE Report of the Royal Meteorological Institute of Prussia for $\mathrm{I} 877$ has been received. It is the thirtieth Report, and like all the foregoing Reports, is published by the Royal Statistical Bureau, Berlin, with which the Institute, since its establishment in 1848, has stood in close and uninterrupted connection. Important changes are in contemplation, the most vital of which are the severance of the connection between the Institute and the Statistical Bureau, and the establishment of an independent central direction for meteorology. The Bureau has done a graceful act in presenting with the Report a highly characteristic portrait of the veteran meteorologist and physicist Dove, who has directed the affairs of the Institute since December 9, 1848 , and who, by the number and thoroughness of his writings and their breadth of view, deserves of all men to be styled the father of meteorology.

AMONG the separate papers incorporated in this Report is a discussion by Dr. Hellmann of the observations of cloud at Crefeld, being in continuation of the author's researches into the cloud-covering of the sky as influencer. by the hour of the day, the season of the year, and geographical situation. The daily maximum occurs at Crefeld, about, or a little before sunrise, from September to April, whereas, from May to August, the maximum is from about II A.M. to 3 P.M. The monthly maximum, which holds also for all hours of the day, is December, whilst the month with clearest skies is September. The barometric observations at Berlin for the past thirty years are carefully discussed by Prof. Arndt, from the general results of which it appears that the great summer depression of the barometer which is so characteristic a feature of the climatology of the Europeo-Asiatic Continent, is not shown at Berlin, it being a little to eastwards of Berlin, to which the limits of the western outskirts of this widespread barometric depression extend.
THE Dutch Meteorological Institute has issued Wind Charts of the North Atlantic, Series I., including the six months from December to May. The region covered by the charts lies between $5 \mathrm{x}-30^{\circ} \mathrm{N}$. lat. and $4-52^{\circ} \mathrm{W}$.long., and between $30-8^{\circ}$ N. lat., and $13-39^{\circ}$ W. long. The frequency of the different winds is graphically shown by radii, the length of each being proportional to the fre quency of the particular wind it represents. Instea fregrouping the observations into $5^{\circ}$ squares and into seasons as has been generally done, Dr. Buys Ballot has presented the facts on the charts for each $I^{\circ}$ square and for each month, the object being to lay down the geographical position of the winds of this region, so important to navigators as well as men of science, with the closest approach to truth and least possible admixture of hypothesis.

IN a circular letter addressed to the Permanent Committee on Meteorology, Prof. Hildberandsson invites the co-operation of all meteorologists to the carrying out of a more systematic observation of the upper currents of the atmosphere than has yet been attempted. Hitherto the observation of the upper clouds and the directions in which they march, has been confined to isolated observers whose services were enlisted through the enthusiasm of individual meteorologists. But fragmentary and scattered though the observations have necessarily been, the results fairly deduced from them are of so important a nature from their bearings on the great problem of atmospheric circulation, that we have no hesitation in giving our hearty support to Prof. Hildebrandsson's proposal that the meteorological societies and observatories make observations of the movements of clouds, chiefly of the upper clouds, part and parcel of their regular observations, and that the results regularly appear in their publications.

THE great storm of September 15-16, so widely and so severely felt, deserves to be specially noticed on account of the low barometers accompanying it, which were not only exceptionally low for the season but even exceptionally low for any season of the year. From the observa. tions made at the stations of the Scottish Meteorological Society in the north and north-west it is seen that at Thorshavn, Farö, the barometer at $32^{\circ}$ and sea-level fell at 9 P.M. of the 15 th to 28.058 inches, being the lowest point to which it fell, and about that time the wind shifted from south-east to north-west. At Stornway the barometer fell to its lowest, 28.400 inches at 7 P.M., or two hours earlier than in Farö; at the same hour it fell to the lowest point, 28.457 inches, at Monach lighthouse, the wind at this time attaining its maximum violence during the storm; at Sandwick to $28 \cdot 404$ at midnight; and at North Unst lighthouse it fell during the night to $28 \cdot 305$ inches. Heavy showers with thunder and lightning and heavy continued rain occurred in the Northwest Highlands, nearly an inch of rain falling in less than an hour at Portree on the morning of the 15 th, and 10.57 inches at Glenquoich during the six days beginning with the I4th.

\section{GEOGRAPHICAL NOTES}

THE Gothenburg Handels Tidning, of the r6th inst., contains a telegram from Irkutsk, addressed to $\mathrm{Mr}$. Oscar Dickson by Prof. Nordenskjöld, announcing that he had reached the mouth of the Lena on August 27, after having passed Cape Chelyuskin, without meeting with any noteworthy obstacle from ice, and that the voyage would be continued towards Behring's Straits with the highest hopes of success. It is probable that Prof. Nordenskjöld's anticipations have been by this time realised, that the Vega has reached Behring's Straits, and thus successfully accomplished the North-East Passage. News has also arrived that the Lena, a small steamer which accompanied the Vega, has ascended the 
river of the same name, having arrived at the town of Yakutsk on September 22.

DR. GERHARD ROHLFS had finally fixed his departure from Malta for the 2oth instant. He will be accompanied by two Austrian travellers, Dr. Hecker, and Herr von Csillagh. The party will first go to Tripolis, and direct their principal efforts to the investigation of the Shari River, and of the sources of the Binue and Congo Rivers.

CAPT. TYSON, having arrived at St. John's, Newfoundland, has sent a telegram to Washington stating that his voyage has been quite successful, and every part of the task imposed upon him has been accomplished. Capt. Tyson learns with deep regret that all has been rendered useless by the postponement of the definitive expedition.

ON reference to a map of China lately published by Mr. Stanford for the China Inland Mission, it will be seen that the missionaries of that body have for some years past been emulating their Roman Catholic brethren in the energy with which they have pushed their way into various parts of the empire. One of the most remarkable journeys, an account of which has but lately become available, was performed principally on foot, by $\mathrm{Mr}$. John McCarthy, who left Shanghai in December, 1876 , and reached Bhamô on August 26,1877 , having travelled a distance, including detours, of about 3,000 miles. Mr. McCarthy, though taking a somewhat different course, made the same journey as the Grosvenor Mission, and he claims to be the first non-official traveller who has thus Eraversed the entire width of the empire, and crossed the Kah-chen hills to Bhamô. Wearing the Chinese dress, and baving nothing strange or novel with him, he was able to move along without any difficulty through the various towns and cities, and it is certainly worthy of note that throughout the whole of his long and hazardous journey he was not once obliged to appeal to an officer for help of any kind, and in no case did a ny officer put an obstacle in his way. The country, as far as the great commercial mart of Chungking, in Szechuen, is now comparatively so well known, that that part of Mr. McCarthy's journey was tolerably easy, but after leaving Chungking the case is different. Circumstances induced him to make for Kweiyung-fu, the capital of Kweichow; he found that the country due south of Chungking was not at all to be compared with the eastern portion of Szechuen, large tracts of land being uncultivated, towns fewer, the people more scattered, and worse housed and clothed. It would be difficult, he says, to picture the desolation of a great part of the Kweichow province; in consequence of the many years' internal strife, whole districts having been entirely depopulated. After a fortnight's stay in Kweiyang-fu Mr. McCarthy decided to walk westward, as far, at least, as Yünnan-fu, being anxious to test the feelings of the people towards foreigners. The people everywhere continued civil, and no more difficulties were met with in Yünnan than in previous portions of the journey. On the road between Yunnan-fu and Tali-fu Mr. McCarthy remarks that "the people generally are in a deplorable condition: the women compelled to do manual labour, which in other places is confined entirely to men. Men and womenbut especially the latter-suffer from the formation of goitre, some of immense size." From Tali-fu to Têngyuieh, or Momien, Mr. McCarthy says, is really the most fertile part of the country. Yungchang-fu, between these places, has been a fine city, and even now the southern part is well built over, and a good deal of business is done there. Mr. McCarthy found that the fame of the medical work at Bhamô had spread even to Momien, and during the four days' walk to Manwyne he met many Shans and Chinese who spoke approvingly of the wonderful cures effected by the foreign teachers. Having secured the services of a chieftain he crossed the hills in two days, and arrived at Bhamô in safety. This Kah-che chief and his followers professed the greatest friendship for the English, and treated Mr. McCarthy so well that he agreed to return with him in a fortnight, in order to continue his journeys in Yünnan. This plan, however, he was obliged to give up, as he was informed by our political agent at Bhamô that he could not be allowed to re-enter China from Burmah, that being forbidden by the Indian government!

THE Wesleyan Missionary Society have recently received some very satisfactory intelligence in regard to the attitude of the natives towards foreigners in a part of Central China where they had probably never been seen before. Writing from Kwang Chi, Hankow, under date of June 7, the Rev. Thos. Bramfit says, in describing a missionary tour, that, "as Lo Tien, Ma Tsien, and the other towns have not been visited before, the people came out in crowds to see the foreigner, and to hear his doctrine; and it is to be recorded to their credit that without exception they treated us kindly, and seem inclined to give the truth a fair hearing. It may be that the Chefoo Convention has something to do with the change in the temper of the people, as compared with that in other places when first visited; but it struck us that the change is to be accounted for chiefly by the increased intercourse between the people and foreigners."

THE French Government have sent M. Léon Cahun, well known from his researches in Eastern Europe and in Central Asia, to Cyprus, on a special mission, in order to investigate the island in an anthropological and archæological direction.

\section{NOTES}

THE death is announced, on the $13^{\text {th }}$ inst., of M. Delafosse, Professor of Mineralogy in the Paris Museum of Natural History and the Factity of Science.

WE have received a "first proof" of the list of awards made to British exhibitors, from which we cull the following items :A Grand Prix and Diplôme d'honneur have been awarded, in Class 8, Organisation, Methods and Appliances for Superior Instruction, to South Kensington; in Class 15, Mathematics and Philosophical Instruments, gold medals have been awarded to Mr. J.H. G. Dallmeyer, Mr. Howard Grubb, Messrs. A. Léqé and Co., Messrs. Negretti and Zambra, Messrs. Ross and Co., and Sir William Thomson; in Class 16 , Maps and Geographical and Cosmographical Apparatus, a gold medal has been awarded to Mr. Edward Stanford; in Class 65, Telegraphic A pparatus and Processes, a Grand Prix is awarded to Prof. A. Graham Bell, for his magneto-electric [telephone, without electric current; in Class 67, Navigation and Life Saving, a gold medal to Sir William Thomson, for his compass.

ThE Council of the Meteorological Society have arranged for a course of six lectures on meteorology to be given at the Institution of Civil Engineers, 25, Great George Street, Westminster, on successive Thursday evenings, commencing on the 3 Ist instant at eight o'clock. The first lecture will be by Dr, R. J. Mann, on the "Physical Properties of the Atmosphere." The other lectures will be by J. K. Laughton, F.R.A.S., R. Strachan, F.M.S., Rev. W. Clement Ley, M.A., F.M.S., G. J. Symons, F.R.S., and R. H. Scott, F.R.S. Admission to the lectures will be by ticket only, which may be "obtained free on application to the Assistant Secretary at: Great George Street.

IN a lately-issued number of the Proceedings of the America n Philosophical Society, Prof. Cope has given an account of the collection of fishes made by Prof. Orton at various points on the head-waters of the Amazon. Species of the genera Belone and 